\title{
A PhD approach to assessing deforestation dynamics over two decades in two Romanian counties
}

\author{
Alexandru Ioan CRĂCIUN, PhD student \\ University of Bucharest, Faculty of Geography, \\ alexandru.ioan.craciun@gmail.com
}

\begin{abstract}
Deforestation is an increasingly visible and heatedly debated issue in Romania. This PhD thesis aims to join the argument and accurately determine forest dynamics in two counties by comparing satellite data recorded roughly 20 years apart. Additionally, it will attempt to establish a correlation between changes in forest cover and the occurrence of extreme events. If successful, the analysis will subsequently be conducted nationally.
\end{abstract}

Keywords: deforestation, land use, satellite imagery, extreme events

\section{INTRODUCTION}

Deforestation is the process of permanently destroying forests in order to assign a new use to a given territory. The fact that deforestation (especially in tropical regions) is one of the most critical crises of our times has been stressed by various studies for decades (Ludeke, 1990; Laurance, 1999; Bradshaw, 2012).

Deforestation is a complex issue that, if studied thoroughly, can help identify areas that are prone to landslides (Kumar, 2008; Sharma, 2014) and flooding (Bradshaw, 2007; Petrișor, 2014), assess the overall state of biodiversity (Estavillo, 2013) and adjust conservation policies (Andam, 2008).

In the Mediterranean region, anthracology (the analysis of charcoal evidence found in archeological contexts) studies (Vernet, 1999) indicate, as early as the Golden and Silver Ages of the Roman Empire, the replacement of deciduous oaks by evergreen oaks, which hints to the anthropogenic disturbance caused in local ecosystems by the population's growing need for wood, widely used for housing, military purposes and as fuel, against the background of an expanding agriculture (Hughes, 1994).

Another piece of the antiquity puzzle consists of palynology (the study of pollen grains in stratified contexts, e.g. lake bottoms, caves) evidence, which shows that 1.600 years ago, after the fall of the Western Roman Empire, there were a tree pollen frequency low and a notable rise in grass pollen (Lamb et al., 1989). Lamb argues that man-caused forest degradation started roughly $250 \mathrm{BCE}$ and has continued up to modern times.

Although it is estimated that $9 / 10$ of global deforestation occurred before 1950 (Williams, 2001), the best documented period for forest dynamics began in the second half of the 20th century, following the development of satellite technology. The first satellite images that captured various regions worldwide were recorded on August 14th, 1959, by the U.S. Explorer. Later on, in 1972, the United States launched the Landsat Program, which went on to become the longest-standing teledetection program in history (ESA, 2007).

Currently, there is a wide range of rates and causes for deforestation around the world. A recent report published by the World Resources Institute shows that, in 2018, the countries with the highest tree cover loss (including due to natural fires) were Brazil, Democratic Republic of Congo, Indonesia, Colombia, Bolivia, Malaysia, Peru, Madagascar, Papua New Guinea and Cameroon, and that the tropics lost a total of 12 million ha, the equivalent of over three times the size of Belgium.

In the European Union (EU), between 1990 and 2015, forest areas increased by 17 million hectares 
(more than half of which were the result of afforestation programs, while the rest came from natural regeneration), i.e. almost $40 \%$ of the EU's total land area (EEA, 2015).

In Romania, even though official assessments indicate a recent increase of forest areas (MWF, 2016) of 30.000 ha between 2012 and 2016, tens of thousands of complaints were filed regarding potential illegal deforestation activities over the same period (Greenpeace, 2017).

\section{STUDY AREA}

This $\mathrm{PhD}$ thesis aims to compare satellite imagery recorded approximately two decades apart in order to establish the past and possible future forest dynamics in two Romanian counties, and to attempt to establish a relationship between deforestation and the occurrence of extreme events in the analyzed region.

The two analyzed counties, Braşov and Prahova, located roughly in the centre of Romania, are mostly made up of mountainous and hilly terrain, and total 1.437.236 inhabitants (National Statistics Institute, 2017), which places them among the country's main tourist destinations, which is consistent with their particularly active construction sector (NSI, 2017), which presumably impacts land use regionally.

Upon comparing the total area covered by the 4 forest Corine land cover (CLC) classes in the years 2000 and 2012 (Figure 1), an apparent decrease of approximately 65.000 ha can be noticed, which appears to have been followed by the aforementioned increase. However, it must be noted that there are different degrees of confidence associated to these classes: 312 Coniferous forest high reliability (90-95\%), 311 Broad-leaved forest and 313 Mixed forest - good reliability (85-90\%), 324 Transitional woodland-shrub - moderate reliability (80-85\%) (EEA, 2006).

Such a comparative analysis can also be helpful in determining land use dynamics within protected areas in the two targeted counties (roughly one third of the territory). Before the adoption of Government Emergency Ordinance (GEO) no. 75/19.07.2018, numerous protected areas throughout the country did not have custodians - a new national agency was created in order to address this issue - and, consequently, strict compliance with the relevant regulations could not be ensured in a uniform manner nationally.

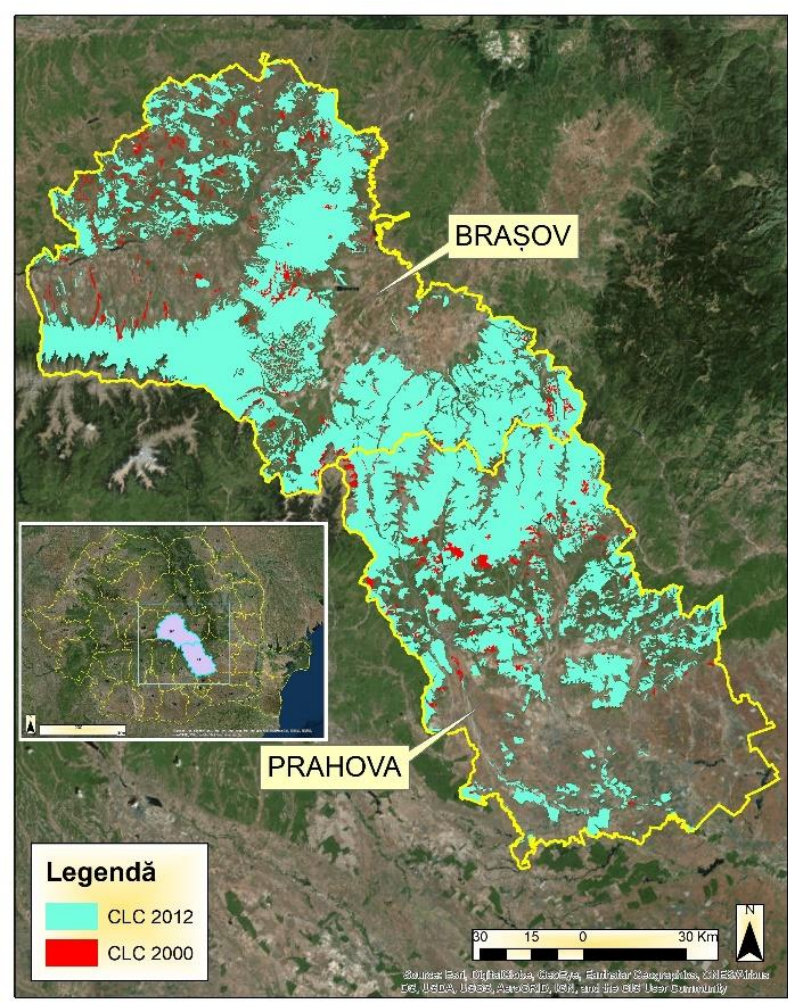

Figure 1. Study area. CLC 2000 vs 2012 (forests)

There are a (small) number of scientific papers tackling deforestation and its effects in Romania, two of which analyze the evolution of an urban landscape (Sinaia, Prahova County) between 1857 and 2009 using Landsat imagery, topographic maps and orthophotos (Huzui, 2011), and the changes in forested areas between 2002 and 2015 in Iezer Mountains (Argeș County, in the vicinity of Braşov and Prahova) (Mihai et al., 2017).

Additionally, in 2010, using CLC data, Dutcă analyzed land cover changes nationally between 1990 and 2006, as did Petrișor in 2014, who compared two periods, 1990-2000 and 2000-2006.

\section{METHODOLOGY}

The data collection and processing phases are presented schematically in Figure 2 and further details are provided below. 


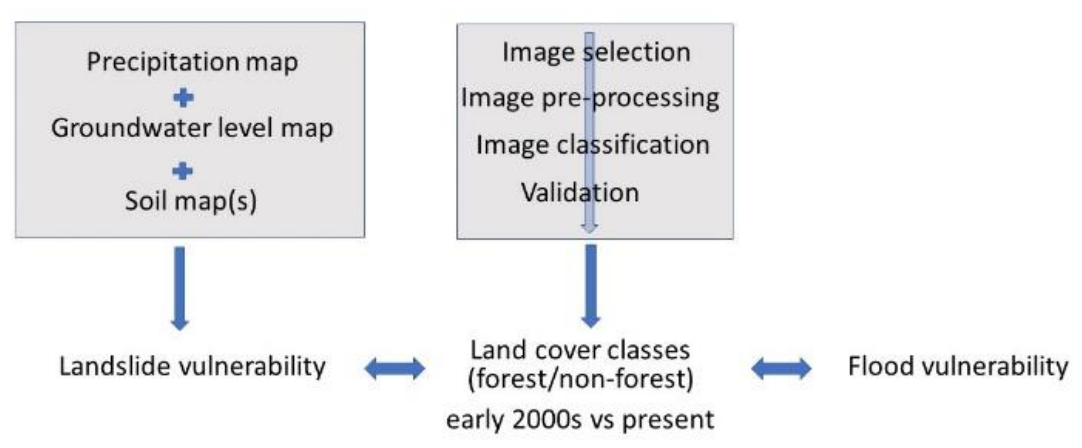

Figure 2. Data processing phases

This $\mathrm{PhD}$ thesis will be largely based on satellite data quality, which means the data sets will have to be carefully selected and processed. The first phase will entail an inventory of freely-available satellite data - Sentinel $1 \& 2$ (accessible on the European Space Agency's online platform), Landsat (via the USGS Earth Explorer platform), GOES-15 (NOAA digital library), NASA Reverb Data Hub (which grants access to data recorded by satellites Aqua, Terra, Aura, TRMM, Calipso, NASA DC, JASON, ENVISAT, ALOS, METEOSAT, GOES, ICESAT, GMS, NIMBUS, SMAP, RADARSAT) - and, if necessary, purchasing the data will be considered (e.g. GeoEye-1, IKONOS, Pléiades 1A/1B, SPOT 6/7, RapidEye).

Additionally, weather data will be collected from the National Meteorological Administration, and extreme events data from the Institute for the Study of Extreme Events.

\section{Image pre-processing}

Satellite data sets recorded in different decades can be compared once a radiometric correction procedure is applied (relative radiometric normalization - RRN) (Yang, 2000), e.g. using the Radiometric Calibration tool featured in the ENVI or ImgTools software (Souza et al, 2013), which cancels errors and corrects lighting variations (satellite recordings of the energy emitted or reflected from a surface on the ground can vary depending on the sun's azimuth and elevation, as well as on atmospheric conditions), based on a reference set.

Additionally, if the satellite recordings provide poor data due to cloud cover, a selection (masking) process will be used to generate cloud-free data (Wedastra, 2013). The sufficiently high-quality data will be selected using image quality-based band information, i.e. Pixel Reliability and VI Quality (Solano, 2010).

\section{Image classification}

The next phase will consist of classifying land use types. Similarly to Carreiras (2014) and Sulistiyono (2018), the satellite data will be processed using supervised classifications based on the maximum likelihood algorithm, which takes several factors into consideration, e.g. the probability of a pixel to be classified into classes or specific categories (Sulistiyono, 2018). Three classes will thus be created, i.e. forest cover, non-forest cover and water bodies, using a specialized image processing software, e.g. ERDAS Imagine.

\section{Validation}

The class accuracy assessment process will consist of computing the Kappa Accuracy (takes all contingency matrix elements into consideration) via an analysis based on the confusion matrix (Olofsson, 2014).

\section{Data analysis \\ Land cover classes}

Once the land cover classes are created and validated, the resulting images will be overlaid in order to establish the extent to which the forest cover class transitioned to a non-forest class or vice versa during the considered timeframe. 


\section{Landslides and flooding}

In the scientific community, it is widely accepted that vegetation helps stabilize steep slopes (Rickli and Graf, 2009, cited in Sharma, 2014). Additionally, several factors influence the process, e.g. precipitation amounts, groundwater level, soil characteristics (Alsubal, 2019).

Based on the quality of available soil data, several or all soil characteristics - depth, inner texture, surface texture, erosion, slope, stoniness, drainage and hydraulic conductivity (Das, 2007, cited in Sharma et al, 2010) - will be mapped, as will the aforementioned factors.

The resulting maps will be superposed in order to identify landslide vulnerability in the two counties, based on a series of scores and classes that will be established at a later stage.

The study will also use flood risk maps developed by the Romanian Ministry of Environment and the Romanian Ministry of Waters and Forests, as part of the 2016 national Flood Risk Management Plan.

Finally, the landslide and flood risk areas will be compared to the resulting forest class changes in an attempt to identify a correlation between forest cover losses (should this indeed be the case) and these extreme phenomena.

\section{RESULTS}

This satellite data comparison-based method was used in numerous studies conducted worldwide with good results, which managed to estimate deforestation and afforestation rates, some of which were already mentioned in the previous sections. However, some shortcomings pointed out by the authors must be mentioned, e.g. the detection solely of forest disturbances that result in $>25 \%$ canopy opening (i.e. low-intensity forest degradation could not be monitored effectively) (Souza, 2013, and Setiawan, 2015), data accuracy issues due to low spatial resolution and to the presence of cloud cover (even after the masking process) (Sulistiyono, 2018).

The most important and useful potential outcome of the study, in addition to obtaining a more accurate regional forest inventory (as this could help confirm or refute the official estimations), lies in possibly establishing a correlation between forest dynamics and flooding and landslide hazard, which could help guide future deforestation and afforestation practices regionally or even nationally. As such, given the scale and aftermath of some of these events (Romanescu, 2017), the results could be all the more relevant and useful to the local population, who could directly benefit from a better understanding of the consequences of current forestry practices.

As the study does not rely on the continent-wide pre-established CLC classes, of questionable accuracy, like other similar analyses conducted nationally, e.g. Dutcă (2010), Petrișor (2014), and given the smaller scale of the study, the findings may provide a clearer image of the actual land cover changes that occurred over the past two decades in the study area.

\section{CONCLUSIONS}

The study is intended to deliver a land cover change trajectory focused on forested areas over a twodecade period. Both deforestation and afforestation (which also includes natural transitions to forests) dynamics will be made apparent by this analysis and, based on the nature and gravity of the findings, forestry practice-related recommendations could be suggested to local decision-makers.

If successful, the analysis will subsequently be conducted nationally.

\section{REFERENCES}

Abhishek, S., Shri, R. (2014). A Review on Effects of Deforestation on Landslide: Hill Areas, International Journal for Scientific Research \& Development, Vol. 2, Issue 7, 37-46

Alsubal, S., bin Sapari, N., Harahap, I., Al-Bared, M. (2019). A review on mechanism of rainwater in triggering landslide. IOP Conference Series: Materials Science and Engineering. 513. 012009. 10.1088/1757899X/513/1/012009

Andam, K. S., Ferraro, P. J., Pfaff, A., Sanchez-Azofeifa, G. A., Robalino, J. A. (2008). Measuring the effectiveness of protected area networks in reducing deforestation, Proc. Natl. Acad. Sci. USA 2008, 105, 16089-16094 
Bradshaw, C. J. A., Sodhi, N. S., Peh, K. S. H. and Brook, B. W. (2007). Global evidence that deforestation amplifies flood risk and severity in the developing world, Global Change Biology, vol 13, 2379-2395

Carreiras J.M.B., Jones J., Lucas R.M., Gabriel C. (2014). Land Use and Land Cover Change Dynamics across the Brazilian Amazon: Insights from Extensive Time-Series Analysis of Remote Sensing Data. PLoS ONE 9(8): e104144. https://doi.org/10.1371/journal.pone.0104144

Corey J. A. Bradshaw (2012). Little left to lose: deforestation and forest degradation in Australia since European colonization, Journal of Plant Ecology, Volume 5, Issue 1, 1 March 2012, 109-120, https://doi.org/10.1093/jpe/rtr038

Dutcă I., Abrudan I. V. (2010), Estimation of forest landcover change in Romania, between 1990 and 2006, Bulletin of the Transilvania University of Braşov Series II: Forestry, Wood Industry, Agricultural Food Engineering 3(52):33-36.

Estavillo, C., Pardini, R., Rocha, P. L. B. (2013). Forest Loss and the Biodiversity Threshold: An Evaluation Considering Species Habitat Requirements and the Use of Matrix Habitats. PLoSONE 8(12):e82369. doi:10.1371/journal. pone.0082369

Hughes, J. Donald (1994). Pan's travail. Baltimore: Johns Hopkins University Press, ISBN 978-0801853630

Huzui A.E., Călin I., Pătru-Stupariu I., (2011). Spatial pattern analyses of landscape using multi-temporal data sources, Procedia Environmental Sciences Volume 14, 2012, p. 98-110

Joshi, N., Mitchard, E. N., Torres, J., Moll-Rocek, J., Ehammer, A., Collins, M., Jepsen, M., Fensholt, R. (2015). Mapping dynamics of deforestation and forest degradation in tropical forests using radar satellite data. Environmental Research Letters. 10. 034014. 10.1088/1748-9326/10/3/034014

Lamb, H.F., Eicher, U. and Switsur, V.R. (1989). An 18.000-year record of vegetation, lake-level and climatic change from Tigalmamine, Middle Atlas, Morocco, Journal of Biogeography 16: 65-74

Laurance, W. F. (1999). Reflections on the tropical deforestation crisis. Biological Conservation. 91. 109117. 10.1016/S0006-3207(99)00088-9

Ludeke, K., Aaron \& C. Maggio, Robert \& M. Reid (1990). An analysis of anthropogenic deforestation using logistic regression and GIS. Journal of Environmental Management. 31. 247-259. 10.1016/S0301-4797(05)80038-6

Mihai, B., Savulescu, I., Rujoiu-Mare, M., Constantin, N. (2017). Recent forest cover changes (2002-2015) in the Southern Carpathians: A case study of the Iezer
Mountains, Romania. Science of The Total Environment. $\quad$ 599-600. 2166-2174. 10.1016/j.scitotenv.2017.04.226

Moreira, J.C., Mello E.M.K., Valeriano D.M., Shimabukuro Y.E., Duarte V., Souza I.M., Barbosa C.C.F. and Souza R.C.M. (2004). Monitoring the Brazilian Amazon deforestation. In: Simposio Latinoamericano en percepción remota y sistemas de informacion espacia, 11. Santiago, Chile. Available at <http://urlib.net/sid.inpe.br/Sergio/2005/02.17.13.57>

Olofsson P., Foody G. M., Herold M., Stehman S. V., Woodcock C. E., Wulder M. A. (2014). Good practices for estimating area and assessing accuracy of land change, Remote Sensing of Environment, vol. 148, pp. 42-57

Petrişor, A. I. (2014). Using CORINE data to look at deforestation in Romania: distribution \& possible consequences, Urbanism Architecture Constructions. 6. 83-90

Rickli, C and Graf, F. (2009). Effects of forest on shallow landslides - case studies in Switzerland. Forest, Snow and landscape Research, 82 (1), 33-44

Romanescu G., Cimpianu C. I., Mihu-Pintilie A. \& Stoleriu C. C. (2017). Historic flood events in NE Romania (post-1990), Journal of Maps, 13:2, 787-798, DOI: 10.1080/17445647.2017.1383944

Setiawan, Y., Lubis, M. I., Malahayati Y. S., Prasetyo, L. (2015). Identifying Change Trajectory over the Sumatra's Forestlands Using Moderate Image Resolution Imagery. Procedia Environmental Sciences. 24. 10.1016/j.proenv.2015.03.025 Sharma, A., Ram, S. (2014). A Review on Effects of Deforestation on Landslide: Hill Areas, IJSRD - International Journal for Scientific Research \& Development, Vol. 2, Issue 07, ISSN (online): 2321-0613

Sharma, L \& Patel, Nilanchal \& Debnath, P \& Ghose, Mrinal (2010). Assessing landslide vulnerability from soil characteristics - a GIS-based analysis. Arabian Journal of Geosciences. 5. 1-8. 10.1007/s12517-0100272-5

Solano R., Didan K., Jacobson A., Huete A. (2010). MODIS Vegetation Index User's Guide (MOD13 Series): Vegetation Index and Phenology Lab. The University of Arizona

Souza, Jr., C., Siqueira, J., Sales, M., Fonseca, A., Ribeiro, J., Numata, I., Cochrane, M., Barber, C., Roberts, D. \& Barlow, J. (2013). Ten-year Landsat classification of deforestation and forest degradation, Brazilian Amazon Remote Sensing Reviews, vol. 5, no. 11, pp. 5493-5513. https://doi.org/10.3390/rs5115493

Sulistiyono, N., Jaya, N. S., Prasetyo L. B., Tiryana T. (2018). Detection of Deforestation Using Low Resolution Satellite Images in the Islands of Sumatra 
2000-2012. International Journal of Sciences: Basic and Applied Research (IJSBAR). 24

Vasantha, K., S. \& Bhagavanulu (2008). Effect of deforestation on landslides in Nilgiris district - A case study, D.V.S. J Indian Soc Remote Sens 36: 105. https://doi.org/10.1007/s12524-008-0011-5

Vernet, Jean-Louis (1999). Reconstructing vegetation and landscapes in the Mediterranean: the contribution of anthracology. Environmental reconstruction in Mediterranean landscape archaeology, 25-36. Oxford, UK: Oxbow Books

Wedastra B. K., Shapiro A., Apriani E., Widiastomo T. (2013). "Sistem Pemantauan Penutupan Lahan Pulau Dan Wilayah (Pemanfaatan Teknologi Penginderaan Jauh - MODIS)," WWF INDONESIA

Williams, M. (2001). The History of Deforestation, History today, Vol. 51, No. 7
Xiaojun, Y., Lo, C. P. (2000), Relative Radiometric Normalization Performance for Change Detection from Multi-Date Satellite Images, Photogrammetric Engineering \& Remote Sensing Vol. 66, No. 8, August 2000, pp. 967-980. 0099-1112IOOI6608-967\$3.00/0

EEA Technical report (2006). no. 7/2006, The thematic accuracy of Corine land cover 2000 Assessment using LUCAS (land use/cover area frame statistical survey), ISSN 1725-2237

European Environment Agency, SOER (2015). The European environment - state and outlook 2015. European briefings - Forests

European Space Agency (2007). 50 years of Earth Observation 2007: A Space Jubilee

Greenpeace (2017). Report on Illegal logging in Romanian forests in 2016

Ministry of Waters and Forests (2016). Report on the state of Romanian forests 